\title{
The Support of Spatial Orientation of Persons with Visual Impairment by means of Modern Aids
}

\author{
Veronika Růžičková ${ }^{1} \quad$ Kateřina Jeřábková $\quad$ Alena Vondráková
}

\begin{abstract}
In the article we introduce the issue of spatial orientation trainingfor persons with visual impairment. We concentrate on the use of modern aids supporting spatial orientation. First we discuss different aids and then audio-tactile maps that are being developed under the project TAČR TL01000507.
\end{abstract}

Keywords: Spatial orientation, mobility, persons with visual impairment, modern aids, audio-tactile aids

\section{INTRODUCTION}

Persons without a disability are not expected to have any problems with spatial orientation and mobility. In contrast, persons with visual impairment face challenges in these areas. We define a person with visual impairment as an individual whose visual acuity is below 6/18 (the individual sees from six metres what his non-impaired peer sees from eighteen metres) or whose field of vision is below 20 degrees (Růžičková\&Kroupová, 2017). It cannot be declared that all persons with severe visual impairment use a white cane while moving but it can be stated that all groups of persons with visual impairment experience certain difficulties while moving independently.

We concentrate on the group of persons with the most severe visual impairment, meaning those whose visual acuity is below 3/60 or whose field of vision is below 10 degrees.Because in the Czech Republic, this group is legally entitled to support while attending compulsory education and also as adults receiving social services.

Mobility skillsand spatial orientation in visually impaired individuals can be supported not only by well-trained instructors of spatial orientation and mobility but also by the use of different technical aids and means. These aids, along with audio-tactile maps will be described below.

\section{Spatial Orientation and Mobility of Persons with Visual Impairment}

Mobility and spatial orientation are the prerequisites for encouraging independence and self-sufficiency of persons with visual impairment. They usually become invaluable when concerning their self-esteem and self-confidence. Additionally, the level of spatial orientation is, from the point of view of majority, seen as the primary sign of independence and success of the person with visual impairment.

The ability to move independently and orientate in space is primarily and fundamentally affected by severe visual impairment; consequently adequate compensation mechanisms are necessary to cope with it, particularlywithout depending on seeing persons. It is agreed that almost any person with severe visual impairment experiences considerable difficulties with spatial orientation but only those with

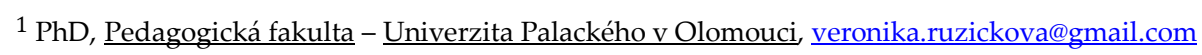


visual acuity below 3/60 or field of vision below 10 degrees (or those with visual impairment progressing to this state) practice well-planned and targeted activities that lead to the development (or re-development) of habits in the field of spatial orientation and mobility.

V. Růžičková and K. Kroupová (2017) state that for persons with visual impairment to successfully develop skills in spatial orientation and mobility (further O\&M), not only is it necessary to utilize the appropriate methodology (described below) but also to consider additional circumstances that can influence the realisation of those activities positively, such as:

- $\quad$ time of onset of visual impairment

- causes of visual impairment and additional complications (additional impairment can play a significant role, e.g. vision loss as the consequence of diabetes mellitus, or visual impairment combined with limited mobility, etc.)

- existing experiences of the person

- timely supply of basic support services

- family background.

All of the abovementioned aspects and circumstances are important for the development of spatial orientation, and some of them are even key ones, but we should not forget the basic influencing factor the personality of the individual with severe visual impairment, meaning his/her intellectual abilities, will, skills, motivation, temperament and other personal characteristics and also overall individual potential.

Step-by-step traininginspatial orientation and mobility is provided forboth children and adults with visual impairment in the Czech Republic, and also in Slovakia. The training steps are gradual and follow each other in a set order; the training sequence is the same for children and adults, though the methodological approach differs for the two groups. The person is prepared to move independently as soon as the training is finished and successfully passed. This step-by-step training was invented and methodologically grounded by Pavel Wiener in the late 1970s and it became a part of the compulsory educationalcurriculum in the late 1990s, as an ungraded subject. The training starts withbasic mobility without the use of a white cane (trailing method, safety positions, walking with the guide, development of natural mobility and orientation abilities of the individual - walking straight, walking up and down the stairs, stability training, hearing differentiation, etc.), which is followed by training mobility with the white cane (from the easiest towards the most difficult trails when the person is obliged to find a given target area) and moreover by analytic-synthetic activities. (Hrbáčová \& Růžičková, 2018; Růžičková, Vondráková, Kroupová, Hrbáčová, \& Melounová, 2018).

As mentioned above, adaptations in the physical environment and the use of aids can support the spatial orientation and mobility of person with visual impairment while moving on short and also long paths. Those will be described in the following part of the article.

\section{Adaptations in Physical Environment and Technical Aids Supporting Mobility}

Aids supporting mobility and spatial orientation of persons with severe visual impairment have a long tradition and they can be sorted into three basic groups:

A) Adaptationsin physical environment 
Adaptations in the physical environment that support persons with severe visual impairment while walking on pathsinclude not only a safe physical environment without obstacles at head level andfences or borders securing dangerous places, but also tactile guiding lines/strips (Figure 1), or tactile surface warning studs and strips (Figure 2), that help individuals to locate indicators for orientation or provide them with directional instructions. These can be supplemented by signs in the Braille alphabet and also by acoustic technical aids.
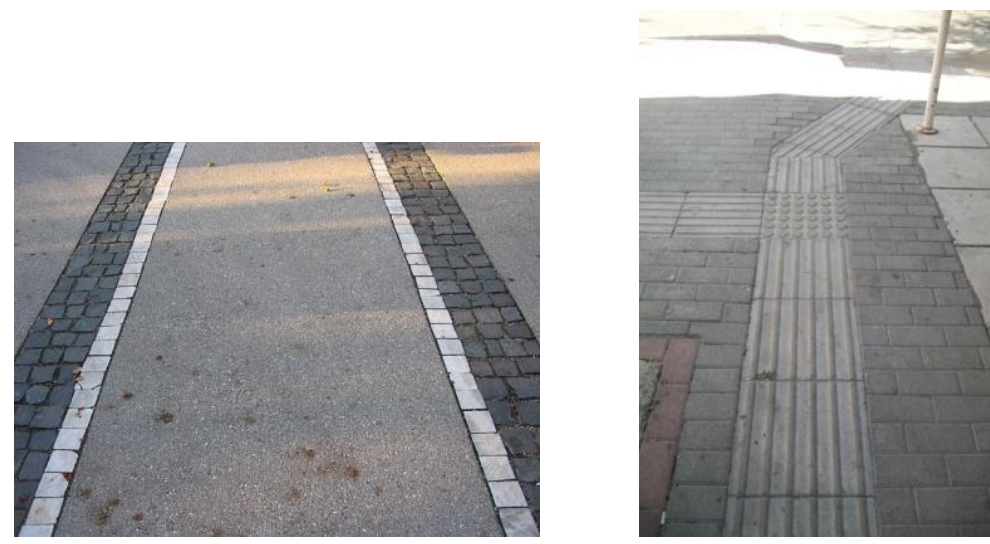

Figure 1. Tactile guiding lines/strips

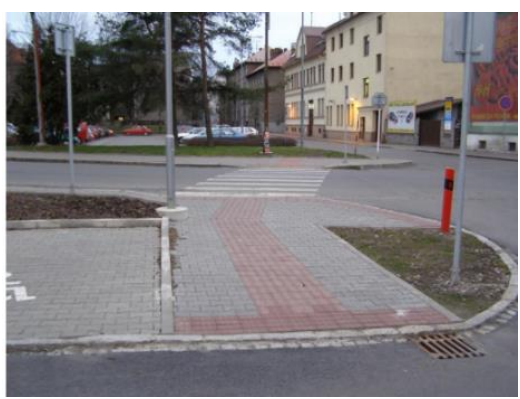

Figure 2. Tactile surface warning strips (Novák, 2009)

B) Classic

Classic technical aids include the white cane, beacons with acoustic or digital voice signalling (Figure 3), traffic lights with sound signals or public transport using sound and voice signals, elevators with voice output, and personal remote control of acoustic mobility devices (Figure 4), which enable the user to hear acoustic information from beacons in traffic lights, public transport, transport stops, buildings, and other locations equipped with compatible technology. 

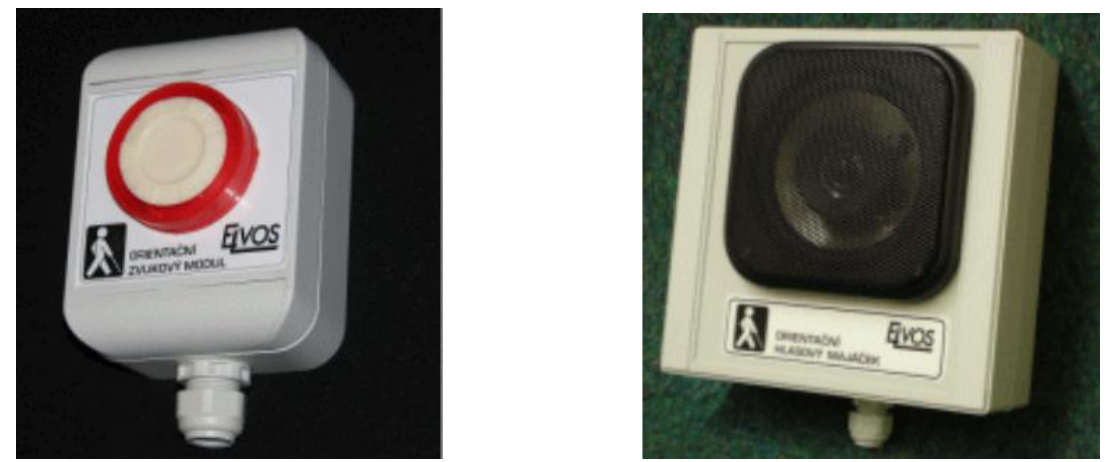

Figure 3. Beacons with acoustic or voice signalling (Retrieved from: http://www.tyflocentrumol.cz/app/clanek/580/hlasove_majacky)

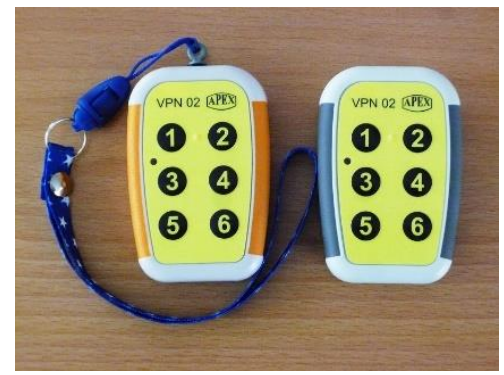

Figure 4. Remote control of acoustic mobility devices (Retrieved from:http://www.apex-jesenice.cz/ tyfloset9.php?lang=cz)

\section{C) Modern}

These high-tech aids usually work on the basis of electronics, GPS modules and voice output. This issue was addressed in an article by Melounová, Z, Růžičková, V. and A. Vondráková (2018). The following section about modern aids is quoted from this article.

\section{$\underline{\text { Smart station }}$}

The concept of the smart stop (Figure 5) is represented by electronic panels located at public transport stops. Current information about transport connections is shown on the display. Smart stops are equipped with a voice output for persons with visual impairment. The voice output is activated by pressing button 1 on the user's remote control ofacoustic mobility devices(see above, Figure 4). The panel reports line numbers and directions according to their departure time. 


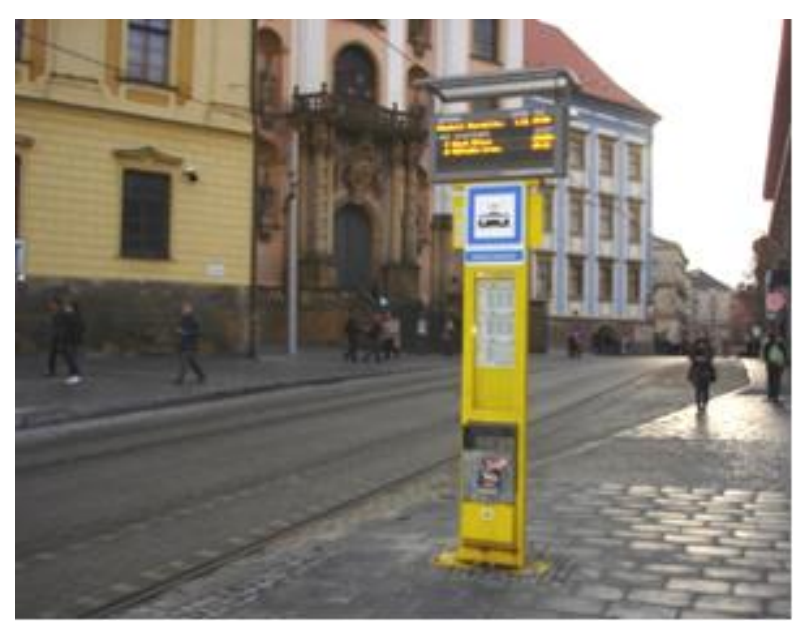

Figure 5. A smart station in Olomouc (Novák, 2009)

\section{EZOP Panel}

The EZOP panel (Elektronickýzobrazovací panel) (Figure 6) provides information on departures and arrivals of public transport. It also provides information about delays, describes the local vestibule and pathways to the platforms, and last but not least, introduces the listeners to the sights that are in the city. It is tailored for both users with visual impairment who have the ability to magnify the information displayed, as well as for the blind, as it is equipped with voice output. A signal is triggered by button number 5 on the user's remote control of acoustic mobility devices. This signal assists blind people in determining the position of the panel. Below the display there are four control buttons, all of which are of course embossed. This aid is installed, for example, in the Czech capital Prague at the main railway station, and in some train or bus stations. The panel can also be used as an information panel in banks, offices, cultural facilities, or other places commonly visited by members of the public.

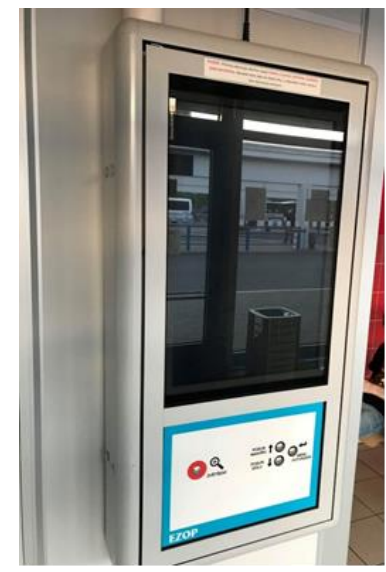

Figure 6. An EZOP panel (Novák, 2009) 


\section{GPS Modules}

Global Positioning System (GPS) modules have been used by individuals with visual impairment for more than ten years. They are still being tested and refined. Today both exterior and interior guidance systems are in use. In addition to various applications (such as CelTrack, PST, Loadstone, and others), there is another option to use GPS navigation through the SONS Navigation Centre. Czech Blind United, known as SONS (Sjednocená organizace nevidomých a slabozrakých), founded this navigation centre 5 years ago. Its main objective is to enable persons with visual impairment to travel independently and to move in an unknown environment - without a guide or assistant present, only with a white cane or a guide dog. This type of navigation works provided that the blind person has a navigation unit that will turn it on if necessary. The GPS navigator focuses on the exact location of the caller and navigates him/her towards his/her destination via the phone. The navigation centre has gradually expanded its services, so it is now possible to prepare a written route itinerary for users in advance. This high-tech aid, together with the navigation centre, helps an individual with visual impairment toapproachhis/her destination, to search for transport connections, and to use a number of other services offered. In addition to the navigation units, persons with visual impairment can also use the so-called "modern cane". This cane was developed at the Czech Technical University in Prague and it is equipped with a navigation unit (SIM card with GPS locator).

As technical aids that themselves support spatial orientation were discussed above, the following section will focus on aids that support better understanding of spatial relationships - maps and plans.

\section{Maps and Plans Used by Persons with Severe Visual Impairment}

Since the introduction of O\&M training, instructors/O\&M specialists have considered approaches to presenting the path to their clients - how to illustrate the path and the movement along this path. The oldest way of illustrating space for persons with severe visual impairment was drawing the path in the sand, later on to clay or wax tablets, and so on. These methods were slowly replaced by more sophisticated ones - carving the path into wood, casting it from plaster or bronze (Figure 7), making it from different materials by hand (cutting it and gluing it together), or other artistic methods.

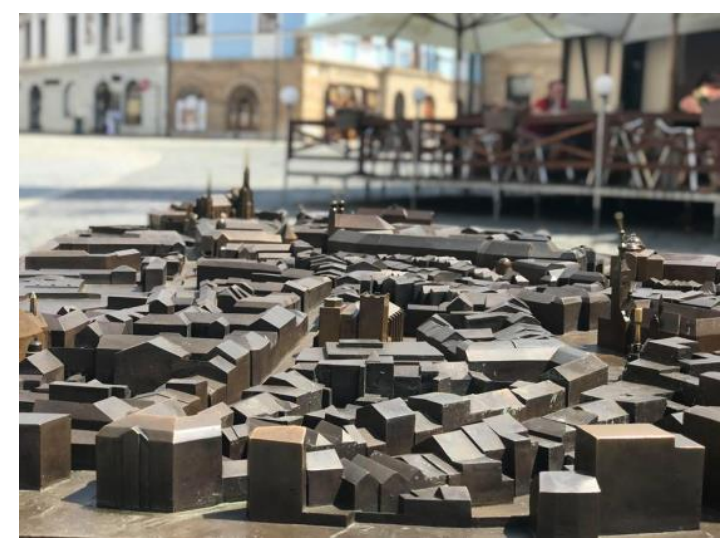

Figure 7. A bronze model of Olomouc (Melounová et al., 2018) 
However, modern technologies now offer the possibility of printing maps for everyday use in schools and social services - first it was fusers (Figure 8) and later on 3D printers. In the past, 3D printers were rare and printing was expensive (Voženílek \& Vondráková, 2014). At Palacký University, the first 3D printers were used for blind persons in 2010 (Figure 9).At present, the printers use not only ABS filaments for printing but they also use layering of paper or another materials (Vondráková, Barvír, Voženílek, \& Brus, 2018).

3D maps printed on those printers can be linked to tablets or computers by conductive filaments and they can be equipped with sound via a specific application and therefore supply important information to persons with visual impairment. The project we introduce further is based on the utilization of thesepossibilities.

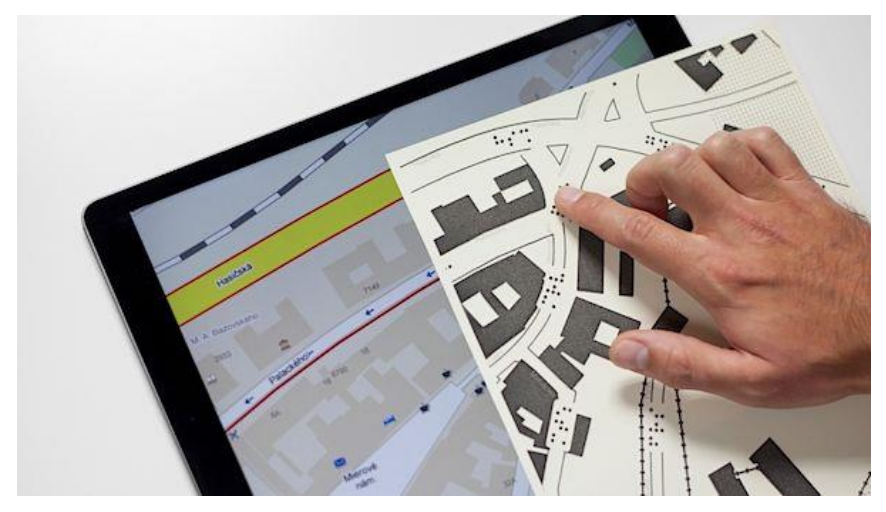

Figure 8. A Tactile map printed on a fuser (Retrieved from: https://www.novinky.cz/internet-apc/419074-mapy-cz-nove-pomohou-nevidomym-s-orientaci-i-na-slovensku.html)

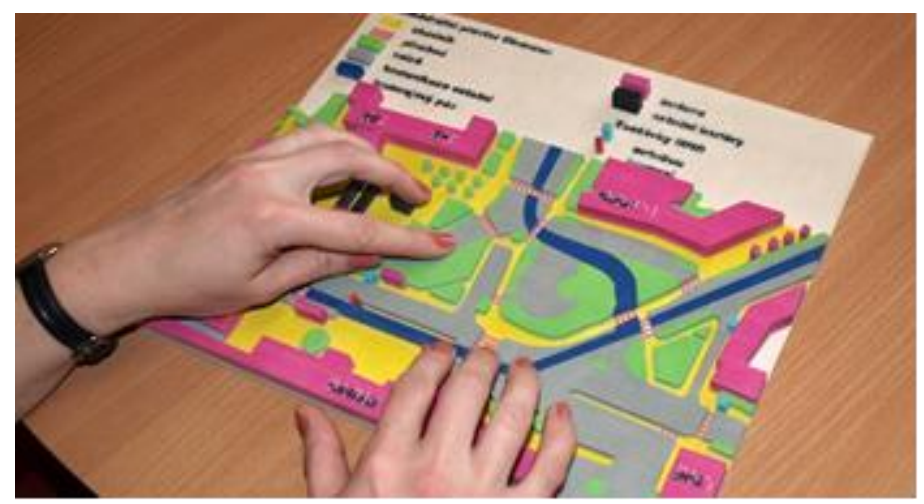

Figure 9. A 3D coloured map with printed braille and latin alphabet

\section{Project TAČR - TL01000507 Development of Mobility by the Use of Audio-Tactile Means}

The project's aims are the development of 3D tactile maps created by the means of modern 3D printing technologies, and the development of software linking maps to tablets to create audio-tactile maps. 
Apart from the invention of audio-tactile maps, new training materials, including a set of audio-tactile maps, and training methodology will be produced. The final objective of the project is to train persons with visual impairment in using these maps according to the new methodology.

\section{Current State of the Research}

Prototypes of tactile maps were created on the basis of acquired knowledge in the field of O\&M and cartography andknowledge of the technology invented at the Department of Geoinformatics, Palacky University Olomouc. The research is focused on the user issues in geovisualization (Vondráková\&Ro̊žičková, 2018; Vondráková, Růžičková, and Barvíř, 2018). These prototypes underwent user testing. First, the area of tactile graphics and cartographic semiology was examined. In order to test the suitability of the height differences between the layers, thickness of lines, point character sizes, line structures, surface textures, and other variables several sample tactile graphics were produced.The sample tactile graphics were created in two colours in order to differentiate red map characters from the white background and consequently be more illustrative for persons with low vision (Figure 10).

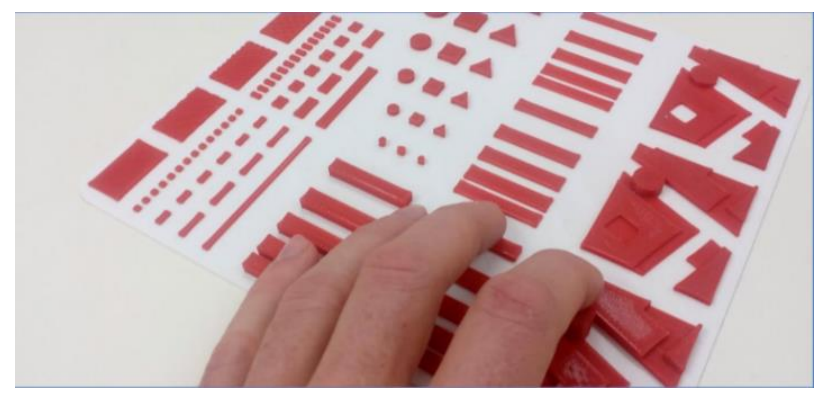

Figure 10. A sample produced to test the height of layers and surface textures

The first tactile maps designed for user testing were created for three chosen locations in Ostrava, Opava and NovýJičín. The localities were selected in cooperation with the project'simplementation partner, i.e. representatives of the charitable organizationKafira. The size of the tactile maps was adapted according to the size of testing devices (tablets) and also to capabilities of the 3Dprinter. The final selected size is $208 \times 130 \mathrm{~mm}$. The scale of the map was always adapted so that the whole area of interest was as detailed as possible. The tactile maps were developed in the programme SketchUp 8 on the basis of field investigation and cadastral maps. Maps were completed into location sets. Every set consists of a map with pavements, a map with buildings, a map with roads, and a composite map with all of the previouslymentioned layers (Figure 11).The created sets of maps were linked with an as-yet-unnamed application for IOS tablets developed by colleagues from the Department of Geoinformatics, Palacký University Olomouc (Figure 12) and then given to clients of the implementationpartner for testing. 


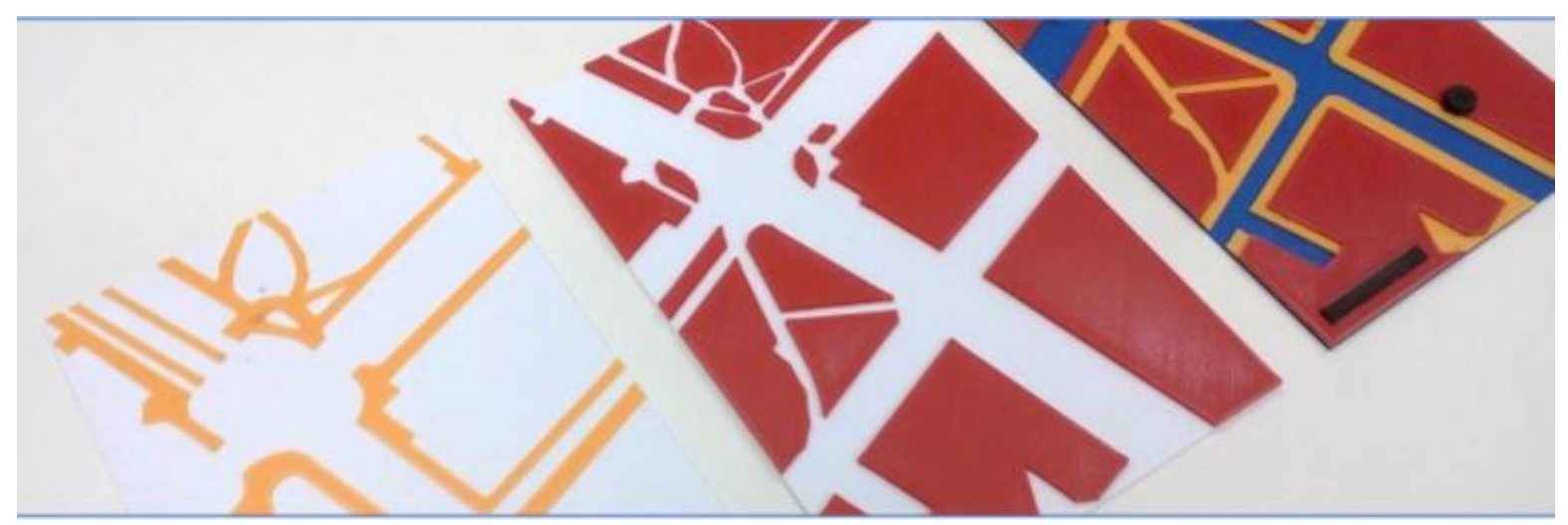

Figure 11. A set of tactile maps

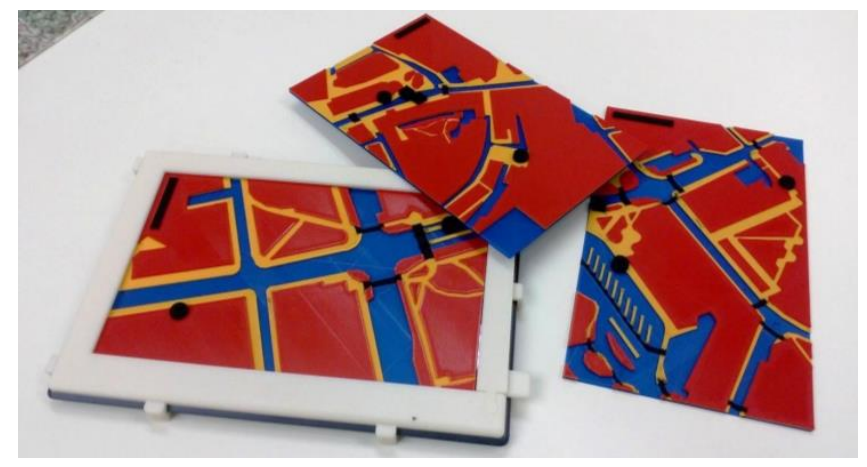

Figure 12. 3D maps linked to tablet

\section{User Testing}

User issues and user testing are very important in the process of map creation (Vondráková\&Voženílek, 2016). User testing was conducted in several phases. Qualitative testing took place during the first phase (in 2018). The aim of this phase was to gain knowledge and comments on map prototypes. Representatives of target groups of both sexes aged 10 to 67 years were tested from October to December 2018. The group of participants consisted of persons with diagnosis of macular degeneration, cortical visual impairment (CVI) and also with genetic impairments, all of which manifest in visual impairment ranging from severe visual impairment to complete blindness. Pilot testing and further work with the maps provided us with the information that had to be reflected when producing another set of didactic material.

For example, information about the preferred location of the map scale on tactile maps was obtained. Additionally, the conductive elements and consequently multimedia functionality were evaluated and information about the necessary proportions of conductive characters and adequate timing was gained. Several possible colour combinations were proposed in order to find the most suitable contrast of map layers for persons with severe vision loss. The question of appropriate raster design including the possibility of using Braille captions was discussed. Information about cartographic visualisation by tactile-graphic means was collected. Based on testing samples, it was discovered that it would be more appropriate to use a better resolution of printed layers. It had been too high, and consequently when the 
buildings were too close to each other and therefore the roads too narrow, then the pavements could not be found by touch. It is necessary to consider the layer height; future testing will include maps with $1 \mathrm{~mm}$ layers rather than the originally tested $2 \mathrm{~mm}$ layer height. Conductive characters should be triangular rather than round because therespondents younger than 20 years reported problems while using two or more shapes for characters, due totheir limited experience.

In the next project period a new didactic set of prototypeswill be printed, which will reflect the outcomes of previous testing. Forfurther qualitative and also quantitative testing, the sample of respondents will be extended.

\section{Conclusion}

We are surrounded by modern technologies as well as by various questions concerning their value. Many question whether they make our lives better or whether they separate us from real relationships, and wonder whether it might be more appropriate to limit their use and learn to work without these technologies in some fields.However, it is indisputable that modern technology has made it possible to compensate, to some degree, for some of the obstacles that people with congenital or acquired disabilities may encounter.

In the article we have introduced not only methods but also aids that serve in the compensation of vision loss in the field of spatial orientation.We also concentrated on modern methods and aids thatcannot replace the classic ones in any way, but that function as an addition and support to quality of life of persons with visual impairment.

This article is affiliated with Project TACR - TL01000507, Development of mobility by the use of audio-tactile means.

\section{References}

Hlasovémajáčky. Retrieved from: http://www.tyflocenrum-ol.cz/app/clanek/580/hlasove_majacky.

Hrbáčová, L., \& Růžičková, V. (2018). Development of independent movement through tactile auditory means. In 5th International multidisciplinary scientific conference on social sciences and arts SGEM 2018. Conference proceedings Volume 5. Science and Society Issue 3.5. Education and Educational research (pp. 181 - 188). Bulgaria: Stef92 Technology.

Mapy.cz nově pomohou nevidomým s orientací i na Slovensku.Retrieved from: https://www.novinky.cz/ internet-a-pc/419074-mapy-cz-nove-pomohou-nevidomym-s-orientaci-i-na-slovensku.html.

Melounová, Z., Růžičková, V., \& Vondráková, A. (2018). Technical means for the development of spatial orientation in the Czech Republic. In 5th International multidisciplinary scientific konference on social sciences and arts SGEM 2018. Conference proceedings Volume 5. Science and Society Issue 3.5. Education and Educational research (pp. 811 - 818). Bulgaria: Stef92 Technology. 
Novák, T. (2009).Akustické, vizuální a reliéfní prostředky usnadňujicí prostorovou orientaci a samostatný pohyb ve městech $z$ pohledu osob se zrakovým postižením. [Czech language](Bachelor thesis). Olomouc: Palacký University Olomouc.

Povelový vysílač VPN 02. Retrieved from: http://www.apex-jesenice.cz/tyfloset9.php?lang=cz.

Růžičková, V., \& Kroupová, K. (2017). Pohlednasamostatnýpohyb a prostorovouorientaciosob se zrakovýmpostižením. Olomouc: VUP.

Růžičková, V., Vondráková, A., Kroupová, K., Hrbáčová, L., \& Melounová, Z. (2018).Possibilitiesof development of spatial orientation and independent movement of persons with severe visual impairment. In 5th International multidisciplinary scientific conference on social sciences and arts SGEM 2018. Conference proceedings Volume 5. Science and Society Issue 3.4. Education and Educational Research(pp. 585 - 592). Bulgaria: Stef92 Technology.

Vondráková, A., \& Voženílek, V. (2016). User issues in geovisualization. In International Multidisciplinary Scientific GeoConference Surveying Geology and Mining Ecology Management, SGEM 2016, Proceedings (pp. 599- 606). Bulgaria: Stef92 Technology.

Vondráková, A., \& Růžičková, V. (2018). The Importance of User Issues in the Cartographic Education of People with Visual Impairment. In $4^{\text {th }}$ International conference on lifelong learning and leadership for all (ICLEL 2018)(pp. 248 -251). Wroclaw:University of Lower Silesia.

Vondráková, A., Barvíř, R., Voženílek, V., \& Brus, J. (2018).The use of modern technologies in the geospace 3D visualization. In International Multidisciplinary Scientific GeoConference Surveying Geology and Mining Ecology Management, SGEM 2018, Proceedings (pp. 681- 688).Bulgaria: Stef92 Technology.

Vondráková, A., Růžičková, V., \& Barviŕr, R. (2018). User issues in tactile cartographic education. In 5th International multidisciplinary scientific konference on social sciences and arts SGEM 2018. Conference proceedings Volume 5. Science and Society Issue 3.5. Education and Educational research (pp. 913 - 920).Bulgaria: Stef92 Technology.

Voženílek, V., \& Vondráková, A. (2014). Tactile maps based on 3D printing technology. In Proceedings of the International Scientifical Conference May 23th-24th, Vol. III, Society Integration Education. Rezekne: Rezeknes Augstskola. Retrieved from: https://www.researchgate.net/publication/282224292 TACTILE_MAPS BASED ON 3D PRIN TING TECHNOLOGY.

Wiener, P. (1986). Prostorová orientace a samostatný pohyb zrakově postižených. [Czech language] Praha: Avicenum. 